\title{
Being Biblical? \\ Slavery, sexuality, and the inclusive community
}

\author{
Richard A Burridge (Dean: King's College, University of London) ${ }^{1}$ \\ Research Associate: Faculty of Theology \\ University of Pretoria
}

\begin{abstract}
The use of the Bible in ethical debate has been central for the last two millennia. Current debates about sexuality, or the position of women in church leadership, are marked by both, or all, sides of the argument using Scripture. However, this has been true of many issues in the past. This is demonstrated in the debate about slavery two hundred years ago. Careful analysis of the use of Scripture in both the justification and critique of apartheid reveals how both sides quoted Scripture in its various modes, such as rules, principles, paradigms, and overall world-view. The biographical nature of the Gospels means that we must set Jesus' rigorous ethical teaching in the context of the narrative of his deeds, including his open and welcoming acceptance of all people. It was an inclusive community of interpretation which changed the debates about slavery and apartheid, and a similar inclusive community is needed today.
\end{abstract}

\section{INTRODUCTION}

Although I never had the privilege of knowing personally my great predecessor, Eric Abbott, I have come to know him through being Dean of King's College London, and through these annual lectures. He was the great post-war Dean, who opened up ordination training to wider groups, started evening classes, educated women for ministry - one of whom has been

\footnotetext{
${ }^{1}$ The Reverend Dr Richard A Burridge, Dean of King's College, University of London, is a member of the International Advisory Board of HTS Theological Studies and a research associate of Dr Andries G van Aarde, honorary professor at the Faculty of Theology, University of Pretoria (South Africa). This article is a reworked version of the twenty-second Eric Symes Abbott Memorial Lecture delivered at Westminster Abbey on Thursday 10 May 2007 and subsequently at Keble College, Oxford.
} 
regular attendee of these lectures throughout my time as Dean. In previous lectures, we have also heard about his work as a spiritual director - and of course, of his work here in Westminster Abbey. He is buried here with his epitaph, "Friend and Counsellor of many, he loved the Church of England, striving to make this House of Kings a place of pilgrimage and prayer for all peoples". Despite this inclusive stress on "all peoples", I have sometimes thought I heard the sound of spinning from his grave in some previous lectures! Last year I passed his service record of twelve years as Dean of King's - so it is perhaps appropriate to be asked by the other Trustees, including his great friends, John Robson and Eric James, to give this $22^{\text {nd }}$ annual lecture at this important and particular time.

Why is it an important and particular time? It is of course 200 years since the abolition of the slave trade - something which caused great consternation in the Church of England and the Anglican family in the colonies at that time. Equally today we face another period of great consternation here and in the world-wide Communion: I want to see if there is any connection between these two debates - about slavery and about sexuality - to see if one can help us with the other. It also allows me to draw upon my academic research over the last decade or more. Of course, slavery and sexuality are two huge topics, as is my own research.

\section{THE CRISIS IN THE ANGLICAN COMMUNION}

The current argument in the Anglican Church over sexuality is only a recent example of debates about the use of the Bible over internal church order and polity, or in external application to war and peace, conquest and colonization. Significantly, often both or all sides of such debates claim to be "Biblical" and accuse their opponents of being hidebound by the tradition or betraying it to the spirit of the age, employing terms such as "conservative" or "liberal". The claim to be "Scriptural" is linked to a desire to be holy, to preserve the community from error, heresy or sin, and so those who want to be "Biblical" can be, or appear to be, "exclusive" in their attitude towards those with whom they disagree. Thus Anglican Mainstream's website defines it as "a community within the Anglican Communion committed to promote, teach and maintain the Scriptural truths on which the Anglican Church was founded. Faithfulness to Scripture as God's Word is essential for sharing the love and purpose of God in Jesus Christ" (www.anglican-mainstream.net).

On the other hand, there is the Inclusive Church network, whose website states: "We have a vision of a liberal, open church which is inclusive of all, regardless of race, gender or sexuality." Yet it also goes on to claim, 
"We firmly believe that this vision can and must be rooted in the scriptures" (www.inclusivechurch.net/inclusivebible).

However, frequently, those who want to be "inclusive" are accused of abandoning Scripture to suit contemporary culture. Thus Philip Turner, former Dean of Berkeley Divinity School at Yale, criticizes recent decisions in the Episcopal Church of the USA: "in place of the complex God revealed in Christ Jesus, a God of both judgment and mercy, a God whose law is meant to govern human life, we now have a God who is love and inclusion without remainder. The projected God of the liberal tradition is, in the end, no more than an affirmer of preferences" (Turner 2003:28-33).

So this debate rages between traditional groups and those who want to be inclusive. The former assume that they are "Biblical", while the latter sometimes also claim this. This is why this lecture is entitled "Being Biblical?" - with a question mark - in an attempt to answer the question. The problem with such debates is that it is often hard to hear each other. All sides have a position, with a pressure group, with websites and mailing lists, and people of similar views meet to plan strategy, motions for Synod, speakers to invite and so forth. There is little opportunity for differing views to come together - and even less for a meeting of minds in the midst of tough debate, dare one even say, in the heat of battle? Yet all of these are Christians, and we are talking about how we read the Bible, how we understand and receive God's revelation and how we try to interpret God's will for his church and the world. There has to be a better way to seek the divine intention.

\section{SLAVERY}

We need to step back from the current intense debate, where everybody thinks they already know what everybody else is trying to say, so that actually nobody is listening to anybody. Instead, can we look at other debates which were equally intense in the past - but which are settled now, to see if we can learn anything. This brings me back to the issue of slavery. This is the $200^{\text {th }}$ anniversary of the British abolition of its Atlantic slave trade, but, please note, not the abolition of slavery itself, which continued to be legal for many years both sides of the Atlantic ${ }^{2}$ - and unfortunately is still very much with us even today. Today the debate of two centuries ago is often portrayed as the slavers' political and commercial power against the brave abolitionist

\footnotetext{
${ }^{2}$ It is interesting how the major full discussions of the abolition of the trade all seem to ignore the question of the Biblical debate; see, for example, Jennings (1997), The business of abolishing the British slave trade 1783-1807; Blackburn (1988), The overthrow of colonial alavery 1776-1848; Rice (1975), The rise and fall of black slavery; Miers (1975), Britain and the ending of the slave trade; Eltis \& Walvin (1981), The abolition of the Atlantic slave trade: Origins and effects in Europe, Africa, and the Americas.
} 
Christians, especially the evangelicals of Clapham sect, who wanted to be Biblical. Thus the Anglican Mainstream website claims that "Those who cited the Bible to justify their views on supporting slavery based their views actually on economic theory, not on the Bible" (www.anglican-mainstream.net). This impression is reinforced by the film, Amazing Grace, which features loan Gruffudd as William Wilberforce singing Newton's hymn to other MPs concerned for trade in ports like Liverpool - using the tune we know today, which was not actually set to those words for another 60 odd years over in America.

But sadly, the caricature that the slavers were just selfish capitalists and the abolitionists were the only Biblical Christians around is just not true. If anything, it was the other way around. Slavery was viewed as a "Biblical" doctrine, supported by the laws of God and human law, while the abolitionists were seen as dangerous liberals, preaching sedition and revolution. This was the time of the American and French Revolutions, the Declaration of Independence and Thomas Paine's The rights of man. Even in the film, Wilberforce has to warn Thomas Clarkson about how dangerous the abolitionist cause could seem. Yet, Thomas Paine only applies the word "slavery" to French citizens during the revolutionary period - not to Africans or the Atlantic trade. Meanwhile, Jefferson and the Founding Fathers of the Declaration of Independence may have believed "these truths to be selfevident: that all men are created equal; that they are endowed by their Creator with certain unalienable rights; that among these are life, liberty and the pursuit of happiness" - but they were all slave-owners, who did not apply these truths to their slaves. In fact, some origins of abolition began as a tactic by the British forces in the revolutionary war of independence to get American slaves to defect. It was extremely successful with tens of thousands running away to British side. Clarkson's brother John, against great opposition from authorities in London, eventually led them back across the Atlantic to found Freetown and Sierra Leone (Schama 2005).

The "Biblical" case for slavery is clear: early in Genesis, Noah decrees that, as punishment for seeing him naked, Ham's descendants will be slaves for Shem and Japheth (Gn 9:22-27); Abraham is blessed by God with "male and female slaves" as a wealthy slave-owner (Gn 24:35; for Abraham's slaves, see also Gn 12:5; 14:14; 20:14). Slaves were part of his estate, property he passed on to his son Isaac (Gn 26:12-14). There is provision in the Mosaic legislation for Israelites to buy and sell slaves, and how to treat them (see e.g. Ex 21 and Lv 25). Slavery was equally accepted in the New Testament, where slaves are told to "obey their masters ... with enthusiasm" as though obeying Christ (Eph 6:5-9; Col 3:22-25; Tt 2:9-10; 1 Pt 2:18-19). 
Paul returns the runaway slave Onesimus to his master Philemon, and tells slaves who hear his epistles to "remain in the condition in which you were called" (Phlm 12; 1 Cor 7:20-24). ${ }^{3}$ Particular attention was drawn to 1 Timothy 6:1-6, where Paul's instructions, "let all who are under the yoke of slavery regard their masters as worthy of all honour" are given the additional dominical authority as "the sound words of our Lord Jesus Christ". All of these texts were common in the Biblical justification for slavery in the early nineteenth-century (Brookes 1850:28).

It was all undergirded by Romans 13:1-7 with its appeal to proper law and order. Wayne Meeks and Willard Swartley have both demonstrated how leading Bible interpreters in universities and churches alike provided "Biblical" support for the "scriptural" doctrine of slavery (Lovering \& Sumney 1996:23253). While today's historical criticism can help, Meeks concludes that "it appears to provide no knock-down argument against such uses of scripture as the apologists for slavery made" (Lovering \& Sumney 1996:245). Even after the British abolition of the slave trade, slavery continued in the southern American states properly supported by Biblical arguments from many theologians, all with DD's (Elliot 1969: 457-521, 841-77). As Swartley concludes, the "appeal to the Bible does not in itself guarantee correctness of position. Both sides in the slavery debate used the Bible to support their positions" (Swartley 1983:58-59). The majority, however, were clear that slavery was Biblical and their attitude to abolitionists was bitter, seeing them as dangerous liberals, undermining the very law of God. As Albert Taylor Bledsoe, LLD thundered, "The history of interpretation furnishes no examples of more wilful and violent perversions of the sacred text than are to be found in the writings of the abolitionists. They seem to consider themselves above the scriptures: and when they put themselves above the law of God, it is not wonderful that they should disregard the laws of men" (Swartley 1983:49, 285).

So here is a parallel between the abolition controversy two hundred years ago and our current crisis in the Anglican Communion between those who want to be Biblical in upholding the tradition versus those who are accused of being liberal in their desire to be inclusive. Yet looking back now, we are all clear that those who claimed to be Biblical were wrong - and the dangerous inclusive liberals are now seen as inspired by the Bible to bring freedom.

\footnotetext{
${ }^{3}$ For interesting discussion of Paul's approach to slavery, see Martin (1990), Slavery as salvation: The metaphor of slavery in Pauline Christianity; Callahan, Horsley \& Smith (1988:153-200).
} 


\section{APARTHEID}

The abolition of the Atlantic slave trade from West Africa to the West Indies and America affected other British colonies. In South Africa, the British authorities in the Cape moved towards the abolition of slavery there over the next few years. However, the Boers, from Dutch stock, saw this as further British oppression of their way of life, which relied upon the labour of the native peoples. In order to escape abolition, they started the Great Trek, moving up from the Cape into the interior. This reached its climax at the battle of Blood River on December $16^{\text {th }} 1838$, where 500 Afrikaners defeated 20,000 Zulus. Such an apparently miraculous victory set the tracks for the Boer supremacy which led eventually to the Apartheid regime of South Africa, which kept the anniversary of Blood River as a day of thanksgiving to God. Apartheid is thus a direct descendant of the controversy about the abolition of slavery.

However, Apartheid is also the most recent example of this debate between being Biblical and being inclusive. Today, we are all clear that apartheid was a terrible doctrine, unchristian, evil and repressive. We praise people like Archbishop Desmond Tutu who wanted to include blacks in society as those who properly read their Bibles. When Tutu was told to keep out of politics because it did not fit with the Bible, he wondered which Bible his opponents were reading! Again, we have the same debate. Hard though it may be to understand today, Apartheid was a Scriptural doctrine, taught by a Reformed, Bible-reading church. Those who wanted blacks included were dismissed as dangerous liberals, radicals, or even communists. They were accused of defending atheism and violence, and were subject to the whole rigours of the "total strategy" of an oppressive police state. Even Archbishop Desmond Tutu as General Secretary of the South African Council of Churches had to undergo detailed legal scrutiny by the Eloff Commission in 1982 (Allen 1995:53-78).

Now it is hard to credit that prayerful, faithful Christians believed that this evil system was "Biblical". However, the fact is that it relied upon Biblical passages, similar to those used for slavery, some of which we shall examine shortly. It was all undergirded once again by an appeal to Romans 13:1-7 and Paul's insistence on a proper obedience for the laws of God and human beings, with the state as the agent of God. This has formed a focus for my own research over the last decade on how the New Testament is used in ethics. Being from a politically active family involved with anti-Apartheid beliefs, I used to think that Afrikaners were all neo-Nazis, and not "real Christians" at all. I assumed that they were hypocrites pretending to "be 
Biblical" as a fig leaf to cover their exploitation of the black community for their own advantage.

However, having spent the last decade working on this in South Africa, I have realised that, even if it was true of some people, this is an unfair picture over all. The Dutch Reformed Church was, and is, a Reformed Protestant church, priding itself on being Biblical. There has always been a concern for the centrality of Scripture, backed up by excellent faculties of Biblical Studies and Theology in major universities such as Pretoria or Stellenbosch. The theological basis for Apartheid, or "separate development" as it is best translated, is a report of the Dutch Reformed Church, significantly entitled Human relations and the South African scene in the light of Scripture, and formally approved by the General Synod of the DRC as recently as October 1974 (Ras, Volk en Nasie 1974). Now this is a problem: it is easy to dismiss the DRC and the Afrikaners as hypocrites hiding behind a Biblical justification. It is much more difficult to face the fact that a Biblically centred church, full of prayerful people, guided by the Spirit, could have come up with a Biblical doctrine that we, only a few years later, find so abhorrent. Furthermore, it is as challenging as it is uncomfortable: how can we be so sure that we are right when we claim to be Biblical? Or will future generations think that we, or parts of our church today, are as misguided in what we think is Biblical now as were those who supported slavery or apartheid?

Accordingly, I set out to analyse how the Bible was used both to support Apartheid by the Dutch Reformed Church, and also the part it played in the struggle for liberation as a test case for how the New Testament is applied to ethics today. The result will finally be published later this year as Imitating Jesus: An inclusive approach to New Testament ethics (Burridge 2007). My approach draws heavily upon my previous work on literary genre as the key to interpret the New Testament, beginning with my doctoral work on comparing the gospels to Graeco-Roman biography (Burridge 2004). In this new book, I analyse the use of the New Testament under Apartheid through the four main literary genres or types of ethical material, namely rules, principles, paradigms or examples and overall world-view (Gustafson 1970:439-444; Hays 1996:209). It's a large study, but let me try briefly to summarize the results.

\subsection{Rules}

This treats the New Testament as moral handbook and looks for material in prescriptive form or the genre of commands: the idea is "for best results, follow the maker's instructions". Such a rule-based reading of the Bible fits into a deontological approach to ethics, to do with moral duty, as Kant, 
Bonhoeffer or Barth. It works well with direct instructions like the Ten Commandments or the Sermon on the Mount but runs into difficulties when deciding which commands are still binding today, particularly when contemporary moral dilemmas do not appear in the Bible. The DRC's Report on Human relations and the South African scene in the light of Scripture interpreted God's command to "be fruitful and multiply" (Gn 1:28) to include the separate diversity of peoples, confirmed in Dt 32:8-9 and Ac 17:26-27 with "the boundaries of their territories" (Ras, Volk en Nasie 1974:14-15). Similarly, commands forbidding the marriage of Israelites with other peoples were used to prohibit mixed marriages in South Africa under article 16 of the Immorality Act (Ras, Volk en Nasie 1974:93-99). These instructions and other passages came together to form what Loubser (1987:ix-x) calls "the Apartheid Bible".

The Report's approaches to Biblical commands were critiqued by Willem Vorster, Professor of New Testament at the University of South Africa, Pretoria, who argued that 'the Bible simply becomes an 'oracle book' of 'proof texts' or 'a book of norms'”; furthermore "both apartheid and anti-apartheid theologians in the NGK [= DRC in Afrikaans] undoubtedly operate with exactly the same view of Scripture. The main difference is the (political) grid though which the Bible is read. In essence there is no difference in the use and appeal to the Bible between apartheid and anti-apartheid theologians" (Hofmeyr \& Vorster 1984:204-219).

\subsection{Principles}

Secondly, we step back from specific commands to look for the principle underlying the texts, such as the love-principle in Situation Ethics, or the liberation principle in South America. The problems are which principle to apply and whether the principle really arises from the text or actually is imposed upon it by the interpreter. In Genesis 1:28, differing exegeses of the same creation stories could lead to the contrasting "principles" of either "separate development" (God made us all different), as argued by the DRC Report (Ras, Volk en Nasie 1974:14-15), or, on the other hand the principle of "unity" (God made us one in our diversity), as argued by Archbishop Tutu and the liberationists. Equally, the Report handling of the story of Pentecost in Acts 2:6-11 produced the principle of everyone hearing "God's great deeds in our own language" - and so they justified separate racial churches, according to language groups, an Afrikaans church, an English church, Xhosa, Zulu and so forth. On the other hand, Douglas Bax criticised the DRC Report's exegesis and produced the opposite principle of the Spirit at Pentecost "breaking down the barriers that separate humanity" (De Gruchy \& Vicencio 1983:128-130). Thus we have the same hermeneutical, interpretative method 
of looking for a principle being applied to the same texts (Creation and Pentecost) - and yet producing two completely contrasting principles for the pro-apartheid government and for the liberation struggle. All of which poses the obvious question, which one is really "being Biblical"?

\subsection{Paradigms/examples}

Bible narratives are the classic stand-by of the Thought for the Day speaker, or a Sunday morning preacher, recounting a scriptural story about travelling patriarchs and then saying, "isn't that just like you and me"? The immediate problem is the vast culture gap between the Biblical world and our own day but this did not stop it being used in South Africa. When the persecuted Huguenots like the De Villiers, or Du Plessis, or all the other French South African surnames escaped through Holland onto leaky boats which finally made it round the coast of Africa to the rich and fertile fields of the Franschoek valley near Stellensbosch in the Cape, "flowing with milk and honey", it is no wonder that they opened their Bibles to the Israelites coming into the Promised Land, and thought "that's us! Thanks be to God!" However, this also led them to view the locals like the natives of Canaan as "hewers of wood and drawers of water", and to apply the material in Joshua and Judges to the Bantu; from such Biblical narratives, they derived prohibitions against mixed marriages, and justified the oppression and slavery of the native peoples (De Gruchy 2005:171-174, Battle 1997:31-32). When the British authorities moved towards the abolition of slavery, then they were seen like the Egyptians, oppressing the chosen ones of God; so the Boers moved inland to defeat the Zulus at Blood River and make their Covenant with God, ceremonially enacted every year on December $16^{\text {th }}$ at the Voortrekker monument in Pretoria, modelled on that of the ancient Israelites (Mbali 1987:191-193). ${ }^{4}$

This Exodus paradigm of God's people escaping from oppression to the Promised Land also of course influenced European settlers in North America, where it led to the decimation of the so-called "red Indians"; arguably it continues to fuel much of the rhetoric and self-belief of the Republican Right today. The irony, however, is that exactly the same Exodus paradigm lies at the heart of much liberation theology, in South Africa as in South America and it led to the black theology which influenced Archbishop Tutu and Allan Boesak. Once again, we have the awkward situation that the same Biblical story is being used with the same method of interpretation and application by both sides, with the Afrikaners as the victims in their own reading, but seen as the oppressors by the black churches. As a member of the "colonial remnant", Snyman links the hermeneutics of the Afrikaans churches with that of

\footnotetext{
${ }^{4}$ On a research visit to the University of Pretoria, I was moved by the way Prof Jan van der Watt of the Faculty of Theology, was able to tell me the story of Blood River twice, once from the Afrikaner perspective, and again from the Zulus' - both viewpoints equally persuasive.
} 
Liberation Theology: "For the one, God is a God of deliverance. For the other, he is a conquering god. Same texts, two views, two experiences" (Snyman 2005:39).

\subsection{World view}

Lastly, we draw even further back to the overall world-view of the Bible as whole, leading to a Biblical theology, like the Barthian approach of ethicists like Oliver O'Donovan and Michael Banner. However, the Bible is not a single book, but a collection of many genres and languages and cultures over many centuries. Fusing it all into a single vision is difficult - and the Dutch Reformed Church viewed their understanding of "human relations in the light of scripture" as Biblical, based upon the whole scheme of creation-fallincarnation-redemption, while the liberationists argued exactly the same for their understanding.

Thus this brief study of the Bible in South Africa leads to a very disturbing conclusion. We must properly recognize that both sides believed in the Bible, based their view upon it and often used the same method of Biblical interpretation (whether rules, principles, examples or world-view) upon the same Biblical passages - yet they came to startlingly different conclusions. It is all very worrying for current claims of "being Biblical". We can only remember the often-quoted letter of Oliver Cromwell to the General Assembly of the Kirk: "Is it, therefore, infallibly agreeable to the Word of God, all that you say? I beseech you, in the bowels of Christ, think it possible that you may be mistaken." However, when we recall that this was the summer of 1650 , and Scotland was supporting Charles II with troops lined up between Cromwell and Edinburgh, as Anglicans based upon Charles' 1662 Book of Common Prayer, we have to ask the same question: who was "being Biblical" and who was mistaken?

\section{A BIOGRAPHICAL APPROACH TO THE NEW TESTAMENT ETHICS}

To move towards an answer, I return to my biographical approach to the Gospels. In my doctoral study, What are the Gospels?, I argued that classical literary theory and a comparison with Graeco-Roman biography leads to the conclusion that the gospels are the same genre as other lives of famous men in the ancient world (Burridge 2004). Therefore, in order to be Biblical, we have to interpret the gospels according to this genre, in the same way as other ancient lives were read. Graeco-Roman biography is very different from modern examples, with the post-Freudian concern for personality and contemporary interest in "celebrity". The ancients wanted to depict the 
subject's character with a portrait of them through a combination of their deeds and words, through anecdotes and stories as much as their sayings or speeches. Furthermore, both the deeds and the words lead up to the person's death, dealt with in some extended detail in ancient lives, as in the gospels; often it will also reveal something further about the person's life, or bring the author's major themes to a climax.

So to be truly Biblical and find the heart of Jesus' ethic, we need to consider both his ethical teaching and his actual practice. As Luke puts it, "In the first book, I wrote about all that Jesus began to do and to teach" (Ac 1:1). Therefore, we have to look at Jesus' sayings and sermons, but also at his actions, in healing, miracles, and the events narrated, in order to grasp the evangelists' portraits if we are properly to understand how Jesus' ethics fit into this. Often those who claim to be Biblical appeal to his words, like the Sermon on the Mount, which are indeed very demanding and rigorous. But to do that alone is to ignore the biographical genre of the Gospels and treat them as just a collection of ethical teachings. Meanwhile, on the other side, the desire to be inclusive can appeal to his deeds, to the narrative about his relationships with people - but again that is only half the story; it needs not to neglect his teachings. To be properly Biblical requires a biographical approach to the gospels' portraits of Jesus through his deeds and words, his teachings and his ministry, and to follow this on through Paul's letters and the rest of the New Testament. This is what I have been engaged upon for the last decade. While the example of the use of the Bible under apartheid forms the test case for my new book, Imitating Jesus, most of it is taken up with a biographical study of New Testament ethics through deeds and words, which I would now like to outline to see if it helps us with being Biblical today.

\subsection{Jesus' teaching}

If you ask most people about Jesus of Nazareth, we find what Goldsmith terms the "common assumption that Jesus was primarily, or most importantly, a teacher of morality" (Goldsmith 1988:177; Carter \&Thompson 1990:128). Yet, amazingly, the gospels do not portray Jesus as just a teacher of morality. Furthermore, to read them as ethical treatises or for moral guidance is to make a genre mistake, for that is not what they are. They are biographical portraits of Jesus which do include some examples of his teaching. However, Jesus' ethical teaching is not a separate and discrete set of moral maxims, but part of his main proclamation of the kingdom of God as God's reign and sovereignty are recognized in the here and now. Such preaching is primarily intended to elicit a whole-hearted response from his hearers to live as disciples within the community of others who also respond and follow, more 
than to provide moral instructions to be obeyed. When he touched upon the major human moral experiences, such as money, sex, power, violence, and so forth, Jesus intensified the demands of the Law with his rigorous ethic of renunciation and self-denial. However, at the same time his central stress on love and forgiveness opened the community to the very people who had moral difficulties in these areas. Therefore, as befits a biographical narrative, we must now turn from Jesus' teaching to confront this paradox in his activity and behaviour.

\subsection{Jesus' example}

Jesus' demanding ethical teaching on things like money, sex and power should require very high standards from those around him, with the result that ordinary fallible human beings would find him uncomfortable. However, when we turn from his words to the biographical narrative of his activity, the converse is true. It is religious leaders and guardians of morality who found him uncomfortable, while he keeps company with all sorts of sinners precisely the people who are not keeping his demanding ethic. He is criticized as "a glutton and a drunkard, a friend of tax collectors and sinners" (Mt 11:19 // Lk 7:34). He accepts people just as they are and proclaims that they are forgiven without the need to go to the temple or offer sacrifice. His healing ministry is directed towards such people and the eucharistic words at the Last Supper suggest that he saw his forthcoming death as being "for" them. A biographical approach means that it is not enough simply to look at Jesus' words and moral teachings; to be properly Biblical involves facing the paradox that he delivers his ethical teaching in the company of sinners whom he accepts, loves and heals. Furthermore, a major purpose of ancient biography was mimesis, the practice of imitation, of following the subject's virtues. This is reinforced by the Jewish habit of ma'aseh, precedence, where the disciple is expected to observe and imitate his master as a way of imitating Torah and ultimately becoming holy as God is holy. Therefore, to imitate Jesus, it is not enough simply to extract his ethical teaching from the Sermon on the Mount; we must also imitate his loving acceptance of others, especially the marginalized, within an open and inclusive community.

\subsection{Paul}

The Pauline letters occupy about a quarter of the New Testament, and contain a wide range of ethical material, dealing with many moral issues. Yet we can still discern the same basic outline as with Jesus. It is still supremely an ethic of response, even though Jesus' preaching of the kingdom has become proclaiming Jesus as king, so that Christology is central for Paul's theology and ethics. Paul's demand for a response to what God is doing is the same, 
with the same centrality of the love command, seen as fulfilling the law, to be lived out within a community of other disciples in corporate solidarity as the body of Christ. The particular ethical issues handled cover similar topics such the state, sex, marriage and divorce, money, property and poverty, and the various forms of human relationships. In all of these, Paul makes rigorous ethical demands, yet also refers to the mixed nature of his early communities. Throughout, he constantly appeals to his readers to "be imitators of me, as I am of Christ" (1 Cor 11:1; see also Gl 4:12; 1 Th 1:6). Exactly what they are to imitate is made explicit in Rm 15:1-7, where he tells his early Christians to "bear with the failings of the weak" and not to please themselves "as Christ did not please himself". He appeals to them to welcome others "just as Christ has welcomed you".

Paul is often seen as uncomfortable reading for those wanting open debate in an inclusive community today. Yet our biographical approach suggests that this is precisely how we should read Paul - as following the creative complementarity of Jesus' rigorous and demanding ethics together with his acceptance of sinners within his community. As the biographical genre of the Gospels means that we should take Jesus' deeds and example into account as much as his words, so the epistolary genre of Paul's letters directs us to set his ethical teaching within the contingent context of his early Christian communities. As Jesus' pastoral acceptance of "sinners" means that his demanding teaching cannot be applied in an exclusive manner, so too Paul's ethical teaching must always be balanced by his appeal to the imitation of Christ - and this entails accepting others as we have been accepted.

\subsection{The four Gospels}

Space does not permit us to go through each of the Gospels and the rest of the New Testament. However, this same combination of words and deeds can be found here also. Each evangelist has a particular ethical slant in his account of Jesus. Thus Mark stresses the ethic of discipleship in the context of eschatological suffering; Matthew demonstrates how Jesus is the truly righteous interpreter of the law; Luke depicts his universal concern especially for the marginalized, while John portrays Jesus as the divine love who brings truth into our world. These different emphases all reflect how Christology is central in their four portraits, but each of them also combines words and deeds, as Jesus' moral teaching takes place in the narrative context of his acceptance of people within an open and inclusive community. All of this is then set forth in their biographical narrative for us to emulate and imitate the example of Jesus' ethical concern and loving acceptance. 


\section{HOW DID THE DEBATE ABOUT SLAVERY CHANGE?}

Given this rapid tour of how the New Testament ethical material must be set within the context of an inclusive community to interpret the Bible, let us now go back to discover how the slavery debate changed. Wilberforce, Granville Sharp, the Clarkson brothers and the Clapham sect used an information campaign to get the British people and the members of Parliament to understand the reality of the slave trade, rather than the myths which abounded. Central was a concern to see the slave as a fellow human being: thus they issued medallions designed by Josiah Wedgwood inscribed with the slogan over a picture of a slave, saying, "Am I not a man and a brother?" (Schama 2005:192-193; Blackburn 1988:139-140). Olaudah Equiano, the freed, educated former slave from Ghana, had his story printed and distributed in 1789 (rapidly becoming a best-seller), so that people could read about his experience. Although John Newton was converted on May $12^{\text {th }} 1748$ and experienced further spiritual awakening a year later, he still continued to work in the slave trade for several more years until 1754. However, his decisive contribution came 33 years later when he wrote down his experiences as Thoughts upon the African slave trade (1787). Thus, if there was Biblical study driving the abolitionists, it was a result of reading and rereading their Bibles in the light of that listening to the experience of former slaves and slave-traders. In other words, they imitated Jesus' example of doing Biblical ethics within the context of an inclusive community - and the crucial change came as a result of having admitted the excluded group into the discussion.

\section{HOW DID THE UNDERSTANDING OF APARTHEID AS "BIBLICAL" CHANGE?}

Biblical interpretation is never a private matter but needs to be validated by the community of believers. The problem is that the pro-Apartheid account of "human relations in the light of scripture" came out of a Bible-reading prayerful Christian community, the Dutch Reformed Church, supported by the best Biblical scholars in their land. When I asked a professor at Stellenbosch University how the DRC got it so wrong, he explained that it was because the authorities would not listen to the voices of "outsiders" such as other world Reformed churches, and also that they stifled the protests "inside" the church, including whites such as Beyers Naude and the pleas of the blacks. That same professor set up the Centre for Contextual Hermeneutics at Stellenbosch in 1991 and it was as Biblical interpretation was related to its political and social context that things began to change. Subsequently, a very 
important development has been the work of Professor Gerald West with his Institute for the Study of the Bible at the University of Kwa-Zulu Natal in Pietermaritzburg. Here he has pioneered a method of enabling the voices of what he terms "ordinary readers" to be heard alongside those of Biblical scholars and church authorities. Once again, therefore, we see the effect of admitting the excluded group, the ordinary black readers in their social context, into the community of those interpreting the Bible and how this led to change.

It is also significant that after the first elections, President Mandela invited Archbishop Tutu to chair the Truth and Reconciliation Commission. Here too, there was an opportunity to listen to the experiences of all involved, from all sides, blacks, whites and coloured, oppressors and oppressed, victims and torturers alike, so that a full understanding could take place. The testimony of the representatives of various churches about their use of the Bible is interesting. Thus Dominee Freek Swanepoel from the Dutch Reformed Church admitted that "the church had erred seriously with the Biblical foundation of the forced segregation of people. We have indeed taught our people wrongly with regard to Apartheid as a Biblical instruction" (Transcripts of the TRC hearings in East London 1997:246-65; cf Cochrane, De Gruchy \& Martin 1998; Ackermann 1999). This is just one powerful example of many places where church representatives confessed that their previous claim to be Biblical was wrong. Again this all followed from admitting the excluded group to the discussion about what the Bible really says.

\section{HOW MIGHT THE CURRENT DEBATE OVER SEXUALITY CHANGE?}

Finally therefore, let us return to where we started to see whether this study of slavery and its recent manifestation in apartheid can help the controversy in the church over sexuality. Currently one side claims that their view is Biblical in all their rhetoric, while the other stresses the need to be an inclusive church. While some of the Scriptural passages to which reference is made are about "order" in a similar manner to those in the debates about slavery and apartheid, the situation is not exactly the same, which means that some attempts to relate these two topics of sexuality and slavery do not work. Thus during the anniversary period, some suggested that as the church overcame Biblical claims about slavery two hundred years ago, it just needs to do the same now about sexuality. Such arguments are too simplistic. Equally, others view the debate in the same terms as Apartheid, namely that the Biblical claim for Apartheid was a cover for racial prejudice and that we must resist prejudice about sexual orientation similarly. In fact, I have demonstrated that 
the Biblical argument to support Apartheid was actually much more than mere prejudice and it needed careful consideration in an inclusive community of interpretation. Similarly, the Scriptural material to do with human sexuality is also very complex, and easy claims by either side to be Biblical should not be accepted at face value.

There is some negative material about homosexuality in the Old Testament, especially within the legislation of Leviticus. Thus it is forbidden in Lv 18:22, but then so is heterosexual intercourse during menstruation in 18:19; similarly the death penalty is prescribed for homosexuality in Lv 20:13, but it is also required for dishonouring or speaking badly about parents a few verses earlier in 20:9. Such material requires careful analysis to explain why this one issue of sexuality is to be singled out today but not the others. Similarly, homosexuality appears in various vice-lists in Paul's letters, such as 1 Cor 6:9-10, but the words used are unusual and still debated among Biblical scholars; meanwhile, once again many other sins are also listed, yet they do not seem to be the focus of great international campaigns. Equally, the often quoted verses about homosexuality in Romans 1:24-27 also lead into another vice-list in 1:28-32, in which many people including "gossips, slanderers, the insolent ... and those who are rebellious towards parents ... deserve to die" yet no one is campaigning for the death penalty for these. There is nothing about homosexuality in Jesus' teaching, beyond his stress on one flesh in his answer forbidding divorce (Mk 10:1-12); it is rather curious for interpreters in a church which permits divorce to use such passages to forbid homosexuality. Therefore, neither the claim by one side that the Biblical teaching is conclusively negative, nor the suggestion by the other that it is simple prejudice on a level with Apartheid should be accepted at face value. Much further and careful study of the Scriptures is needed as it was about slavery and about Apartheid - but such study needs to be undertaken in an inclusive community where the voices of those who have been marginalized need to be heard.

Earlier I stressed the importance of combining words and deeds, holding Scriptural teaching together with the example given in the rest of the narrative. The Biblical teaching about the ethics of sexuality may not be immediately conclusive - but Jesus' example of his acceptance of those who were marginalized and excluded is clear. Equally, I argued that despite his strong moral demands in his letters, Paul also stressed the importance of maintaining an inclusive community with particular regard for weaker brothers and sisters who are to be accepted as we have been accepted. Paul's call to imitate Jesus is also reinforced by the biographical genre of the Gospels with their concern for mimesis, or imitation of the example of their subject. This all 
means that those who want to be Biblical must maintain an inclusive community of interpretation to discover God's will together through detailed study of what it means to be Biblical.

Those who claim to be Biblical often quote the 1998 Lambeth Conference resolution 1:10 because it affirms that "homosexual practice is incompatible with Scripture". However, other important parts of that same resolution commit the church "to listen to the experience of homosexual persons" who "regardless of sexual orientation, are full members of the Body of Christ". Thus the Archbishop has asked Canon Phil Groves to facilitate the "listening process" around the Communion, some of which has been recently published. This is also why the Private Member debates in General Synod in February 2007 were important. Contrasting attempts by both sides to force a decision as each wanted were forestalled by amendments from the House of Bishops. Yet these replacements were themselves significantly amended to "acknowledge the importance of lesbian and gay members of the Church of England participating in the listening process as full members of the Church" in an "open, full and Godly dialogue about human sexuality". Such listening processes and godly dialogue are what is needed if we are to imitate the example of Jesus.

\section{CONCLUSION}

In conclusion, I have argued that to be truly Biblical, we have to imitate Jesus' teaching and his example, his deeds as well as his words. Jesus' demanding ethical teaching cannot be appreciated separately from his behaviour and activity. Both the biographical genre of the Gospels on the one hand, and the ancient idea of imitation and Jewish rabbinic precedent on the other, suggest that Jesus' teaching must be earthed in his practical example, both of calling people to repentance and discipleship - but also his open acceptance of sinners, with whom he spent his life and for whom he died. Unfortunately, all too often those who do New Testament ethics today end up doing one or the other: that is, teaching a rigorist ethic with extreme demands which seems condemnatory and alienates people - or having an open acceptance and being accused of having no ethics at all! Seeking to follow Jesus in becoming both "perfect" and "merciful" as God is perfect and merciful (cf Mt 5:48 with Lk $6: 36$ ) is not an easy balance to maintain, but one which is vital if we are to be properly Biblical.

To study the Scriptures requires the context of an open and inclusive community of interpretation. The movement for the abolition of the slave trade could only discuss what the Bible really said about slavery once slaves and former slave traders were present and their experiences were heard. 
Similarly, change in South Africa about apartheid as "human relations in the light of Scripture" needed the "voices of protest", with blacks present in the Bible studies and their experiences being recounted. Equally, over recent years, we have struggled to read and re-read the Bible about the place of women in church leadership, as deacons, priests and now as bishops, with women participating in the debate and their experience being heard - and we still have some way to go here. The same has been true for debates about human sexuality: in the middle of the last century, divorce was not permissible and remarriage in church was not allowed - on Biblical grounds. But through the debates and reports of the 1960s, 70s and 80s, the experience of marital breakdown was heard and listened to - and then our understanding of a Biblical approach for compassion and care changed how church treated divorcees.

Only such an open and inclusive community which includes homosexuals and listens to their experience can really grapple with what the Biblical teaching is. This is how my biographical approach to Jesus and the gospels, indeed to the whole New Testament, applies to ethical debates. It requires attention to imitating Jesus' words and deeds, to hear the Biblical teachings within the context of an open and inclusive community - and this applies to sexuality as much as to slavery and to apartheid. Such a debate would be a fitting tribute to the memory of Dean Eric Abbott and his own attempts to be inclusive as a "friend of many", concerned "for all peoples". Such a debate within an inclusive community is the only way forward for us today if we truly want to maintain a claim to "being Biblical".

\section{Works consulted}

Ackermann, D M 1999. Faith communities face the truth. JTSA 103, 88-93.

Allen, J (ed) 1995. The rainbow people of God: South Africa's victory over Apartheid. London: Bantam.

Allen, J 2006. Rabble-rouser for peace: The authorised biography of Desmond Tutu. London: Rider.

Battle, M 1997. Reconciliation: The Ubuntu Theology of Desmond Tutu. Cleveland, $\mathrm{OH}$ : Pilgrim.

Blackburn, R 1988. The overthrow of colonial slavery 1776-1848. London: Verso.

Brookes, I L 1850. A defence of the South against the reproaches and incroachments of the North, in which slavery is shown to be an institution of God intended to form the basis of the best social state and the only safeguard to the permanence of a republican government. Hamburg SC: Republican Office.

Burridge, R A 2004. What are the Gospels? A comparison with Graeco-Roman biography. Grand Rapids, MI: Eerdmans. 
Burridge, R A 2007a. Imitating Jesus: An inclusive approach to New Testament ethics. Grand Rapids, MI: Eerdmans.

Burridge, R A 2007b. The twenty-second Eric Symes Abbott Memorial Lecture. London.

Callahan, A D, Horsley, R A \& Smith, A (eds) 1988. Slavery in text and interpretation. Semeia 83/84. (SBL.)

Carter, C W \&Thompson, R D 1991. The Biblical ethic of love. New York: Peter Lang. (American University Studies Series VIII, Theology and Religion.)

Cochrane, J, de Gruchy, J W \& Martin, S (eds) 1998. Facing the truth: South African faith communities and the Truth \& Reconciliation Commission. Cape Town: David Philip

De Gruchy, J W \& Vicencio, C A (eds) 1983. Apartheid is a heresy. Cape Town: David Philip.

De Gruchy, J W 2005. The church struggle in South Africa: Twenty-fifth anniversary edition. Minneapolis, MN: Fortress.

Elliot, E N (ed) 1969. Cotton is king, and pro-slavery arguments comprising the writings of Hammond, Harper, Christy, Stringfellow, Hodge, Bledsoe, and Cartwright on this important subject. New York: Negro Universities Press.

Eltis, D \& Walvin, J (eds) 1981. The abolition of the atlantic slave trade: Origins and effects in Europe, Africa, and the Americas. Madison, WI: University of Wisconsin Press.

Goldsmith, D 1988. New Testament ethics: An introduction. Elgin, IL: Brethren Press.

Gustafson, J M 1970. The place of Scripture in Christian ethics: A methodological study. Interpretation 24, 430-455.

Hays, R B 1996. The moral vision of the New Testament: A contemporary introduction to New Testament Ethics. San Francisco, CA: T \& T Clark

Hofmeyr, J W \& Vorster, W S (eds) 1984. New faces of Africa: Essays in honour of Ben (Barend Jacobus) Marais. Pretoria: UNISA.

Human relations and the South African scene in the light of Scripture. Dutch Reformed Church. Cape Town-Pretoria, 1976.

Jennings, J 1997. The business of abolishing the British slave trade 1783-1807 London: Frank Cass.

Loubser, J A1987. The Apartheid Bible: A critical review of racial theology in South Africa. Cape Town: Maskew Miller Longman.

Lovering, E. H \& Sumney, J. L 1996. Theology and ethics in Paul and his interpreters: Essays in honor of Victor Paul Furnish. Abingdon: Nashville.

Martin, D B 1990. Slavery as salvation: The metaphor of slavery in Pauline Christianity. London: Yale University Press.

Mbali, Z 1987. The churches and racism: A black South African perspective. London: SCM.

Miers, S 1975. Britain and the ending of the slave trade. London: Longman.

Ras, Volk en Nasie en Volkereverhoudinge in die lig van die Skrif. Approved and accepted by the General Synod of the Dutch Reformed Church. October 1974.

Research Institute on Christianity in South Africa (RICSA). Transcripts of the TRC hearings in East London, Nov 17-19, 1997, pp 246-65

Rice, C D 1975. The rise and fall of black slavery. London: Macmillan. 
Schama, S 2005. Rough crossings, the slaves and the American Revolution. London: BBC Books.

Smit, D J 1990. The ethics of interpretation - and South Africa. Scriptura 33, 29-43.

Snyman, G 2005. Social identity and South African Biblical hermeneutics: A struggle against prejudice? JTSA 121, 34-55.

Sumney, J L 1996. Theology and ethics in Paul and his interpreters: Essays in honor of Victor Paul Furnish. Nashville, TN: Abingdon.

Swartley, W M 1983. Slavery, sabbath, war and women: Case issues in Biblical interpretation. Scottdale, PA: Herald.

Turner, P 2003. The episcopal preference. First Things 137, 28-33.

www.inclusivechurch.net/inclusivebible

www.anglican-mainstream.net

www.anglican-mainstream.net/?p=1446 